\title{
Decentralised wastewater treatment effluent fertigation: preliminary technical assessment
}

\author{
W Musazura ${ }^{*}$, AO Odindo', EH Tesfamariam², JC Hughes ${ }^{3}$ and CA Buckley ${ }^{4}$ \\ 'Crop Science Discipline, University of KwaZulu-Natal, P. Bag X01, Scottsville 3209, South Africa \\ ${ }^{2}$ Department of Plant and Soil Sciences, University of Pretoria, P. Bag X20 Hatfield, Pretoria 0028, South Africa \\ ${ }^{3}$ Soil Science Discipline, University of KwaZulu-Natal, P. Bag X01, Scottsville 3209, South Africa \\ ${ }^{4}$ Pollution Research Group, Howard College, University of KwaZulu-Natal, Durban 4041, South Africa
}

\begin{abstract}
The Decentralised Wastewater Treatment System (DEWATS) can provide a potential sanitation solution to residents living in informal settlements with the effluent produced being used on agricultural land. This paper reports on a first step to assess the technical viability of this concept. To do so a pilot DEWATS plant was connected to 83 houses in the eThekwini Municipality. An experiment was conducted in a randomised complete block design with 2 treatments (DEWATS effluent irrigation and tap water irrigation + fertiliser) and 3 blocks. Banana and taro crops were irrigated using an automated drip irrigation system. Data on the weather, crop growth, nitrogen and phosphorus uptake and soil chemical properties were collected. Irrigation with DEWATS effluent was comparable to tap water + fertiliser especially for banana growth and biomass production. Banana and taro required $3514 \mathrm{~mm}$ of irrigation effluent. About 0.0117 hahousehold ${ }^{-1}\left(23.3 \mathrm{~m}^{2} \cdot\right.$ person $\left.^{-1}\right)$ was found to be an adequate area for effluent reuse. Wet-weather storage requirements were calculated to be about $9.2 \mathrm{~m}^{3} \cdot$ household ${ }^{-1}$. DEWATS effluent, after passing through a horizontal flow wetland, was unable to meet banana and taro nitrogen and phosphorus requirements. Nutrient monitoring is required when using anaerobic filter effluent from a DEWATS for irrigating banana and taro.
\end{abstract}

Keywords: banana, intercrop, nitrogen, phosphorus, taro, treated wastewater

\section{INTRODUCTION}

The provision of onsite sanitation to residents living in informal settlements of South Africa, where centralised wastewater treatment systems cannot be afforded (Ashipala and Armitage, 2011, Cross and Buckley, 2016), is one of the major aims of local governments in South Africa (Hoossein et al., 2014). The Decentralised Wastewater Treatment System (DEWATS) is a potential option, since it is inexpensive to operate due to low energy requirements and does not require skilled operators. The DEWATS is a modular system with 4 components (Gutterer et al., 2009, Sasse, 1998). The anaerobic baffled reactor (ABR) and anaerobic filter (AF) of the DEWATS degrade blackwater and greywater to produce biogas and treated wastewater with a low chemical oxygen demand (Barber and Stuckey, 1999). The disposal of the treated wastewater creates both environmental and health concerns (Foxon et al., 2005). High microbial and nutrient (mainly nitrogen and phosphorus) loads in the ABR effluent preclude its direct disposal into water bodies. To meet the South African standards required for discharge into water bodies (DWA, 2013), further treatments which reduce its nutrient load are required and constructed wetlands might be suitable (Almuktar et al., 2015).

After treatment with the ABR and AF, the effluent can then be passed through constructed wetlands for further treatment. There are two types of wetlands (vertical flow constructed wetlands- VFCW and horizontal flow constructed wetlands -HFCW) (Kadlec and Wallace, 2008; Singh et al., 2009). The outflow from the AF will pass through VFCW then through a HFCW. As the water passes through the gravel layers of the wetland nutrients are lost through a

\footnotetext{
To whom all correspondence should be addressed.

e-mail:wmusazura@gmail.com

Received 3 December 2016; accepted in revised form 26 March 2018
}

series of chemical transformations (Ye and Li, 2009). Nitrogen $(\mathrm{N})$ and phosphorus $(\mathrm{P})$ removal through plant uptake is very low in heavily loaded systems, except when frequently harvested free-floating plants are used (Vymazal, 2007). During the process solids are also removed and pathogens are deactivated (Lavrova and Koumanova, 2013), making the effluent safer to use in agriculture. Wetlands cannot remove all the nutrients so the disposal of the treated effluent must be carefully considered. A well-functioning wastewater treatment system must be able to reduce all contaminants to acceptable levels before the water can reach rivers and underground water resources.

The use of treated wastewater on agricultural soils is widely recommended (Fonseca et al., 2007; Pedrero et al., 2010). Irrigation of crops with treated wastewater is important for recycling nutrients and is preferable to direct discharge into rivers (Mateo-Sagasta et al., 2013). This creates a system whereby soil acts as a medium for nutrient retention allowing subsequent uptake by crops (Bame et al., 2013). The average $\mathrm{N}$ and $\mathrm{P}$ excretion $\cdot \mathrm{person}^{-1} \cdot \mathrm{yr}^{-1}$ in Africa is $3.4 \mathrm{~kg} \mathrm{~N}$ and $0.5 \mathrm{~kg} \mathrm{P}$ (Vinnerås, 2002). Since this is based on excreta fertiliser value, irrigation with DEWATS effluent must consider scheduling which takes into account crop water requirements at different stages of crop growth (Jovanovic et al., 1999).

Several studies have reported that treated wastewater increases crop growth and nutrient uptake, and improves soil chemical and physical properties (Bame et al., 2013; Hussain et al., 2002; Mousavi et al., 2015). Planning for wastewater use in agriculture must consider various technical aspects such as the site's physical characteristics, the effluent quality and quantity, land area required and storage requirements during wetter periods. However, this information is often not available. This paper investigated the amount of DEWATS effluent that can be irrigated per unit area to a banana/taro 
intercrop and the amount of storage required during the rainy season. Specific objectives were to (i) characterise the DEWATS effluent (after the AF and again after a HFCW); (ii) determine effects on the growth of banana and taro in an intercrop; (iii) assess the potential of DEWATS effluent as a source of $\mathrm{N}$ and $\mathrm{P}$ for a banana/taro intercrop (iv) calculate banana/taro irrigation requirements with special reference to the study site and (v) use the information to determine land requirements for irrigating banana/taro intercrop with DEWATS effluent as an aid for municipal land-use planning.

\section{MATERIALS AND METHODS}

\section{Experimental site}

The experimental site at Newlands-Mashu Research Facility, located in Durban, South Africa ( $30^{\circ} 57^{\prime} \mathrm{E}, 29^{\circ} 58^{\prime} \mathrm{S}$; altitude $14 \mathrm{~m}$ amsl) is shown in Fig. 1. A pilot DEWATS designed by Bremen Overseas Research and Development Association (BORDA) following recommendations by Sasse (1998) was installed at the site by the eThekwini Water and Sanitation Department (EWS). The pilot plant was connected to the main sewer of 83 houses close to the research site, to allow research in a safely managed environment, where treated effluent passes back into the trunk sewer. The DEWATS plant consists of 3 treatment steps: (i) settling chambers and biogas collectors, (ii) three parallel ABR trains, (iii) two AF modules and (iv) a VFCW ( $9.8 \mathrm{~m}$ length $\times 9.8 \mathrm{~m}$ breadth $\times 0.75 \mathrm{~m}$ height) and a HFCW ( $8.15 \mathrm{~m}$ length $\times 8.11 \mathrm{~m}$ breadth $\times 0.9 \mathrm{~m}$ height) to further polish the effluent. Train 2 supplies almost one third of the total design effluent $\left(14 \mathrm{~m}^{3} \cdot\right.$ day $\left.^{-1}\right)$ to the VFCW and then to the HFCW.
The climate of the study site falls under the humid subtropical agro-ecological region of South Africa with cool, dry winters which are frost-free and hot, wet summers. The site receives an annual rainfall of approximately 800 to $1000 \mathrm{~mm}$ and has a mean daily temperature of $20.5^{\circ} \mathrm{C}$ (Schulze, 1997). The soil at the site is a clay of the Sepane form (Soil Classification Working Group, 1991); an Aquic Haplustalf (Soil Survey Staff, 2014).

\section{Soil and effluent analysis}

Before planting, soil samples were collected from 3 different layers (0-0.3 $\mathrm{m}$ and $0.3-0.6 \mathrm{~m})$ and characterised for their

\begin{tabular}{|c|c|c|}
\hline \multicolumn{3}{|c|}{$\begin{array}{c}\text { TABLE 1 } \\
\begin{array}{c}\text { Soil chemical properties, particle size distribution and bulk } \\
\text { density of the Sepane soil at the Newlands-Mashu field site } \\
\text { before planting }\end{array}\end{array}$} \\
\hline \multirow{2}{*}{ Soil property } & \multicolumn{2}{|c|}{ Sample depth } \\
\hline & $0-0.3 \mathrm{~m}$ & $0.3-0.6 \mathrm{~m}$ \\
\hline Bulk density $\left(\mathrm{g} \cdot \mathrm{cm}^{-3}\right)$ & 1.25 & 1.43 \\
\hline Clay (\%) & 42 & 31 \\
\hline Silt (\%) & 35 & 43 \\
\hline Sand (\%) & 23 & 26 \\
\hline Organic C (\%) & 2.9 & 2.6 \\
\hline Total N (\%) & 0.29 & 0.27 \\
\hline Extractable P (mg.kg $\left.{ }^{-1}\right)$ & 39.3 & 11.9 \\
\hline $\mathrm{pH}(\mathrm{KCl})$ & 5.2 & 5.1 \\
\hline
\end{tabular}

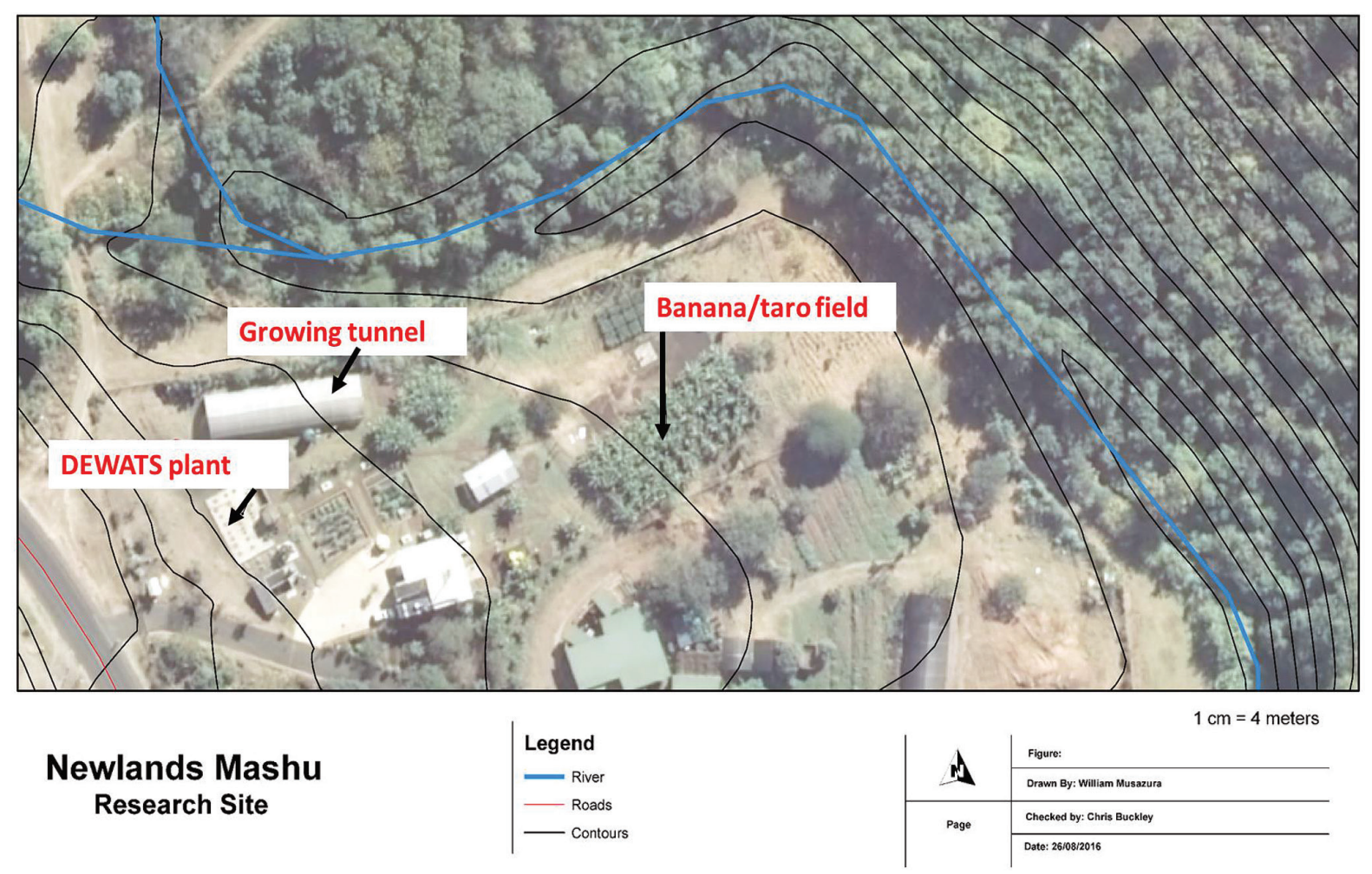

Figure 1

A map of the Newlands-Mashu experimental site showing the decentralised wastewater treatment plant (DEWATS), the experimental field and the nearby river 
physical properties (Table 1). Bulk density was determined from undisturbed soil cores. Particle size distribution was done using the hydrometer method and the soil texture classified according to Soil Classification Working Group (1991). Five soil samples were collected from 2 depths (0-0.3 and 0.3-0.6 m) randomly within each plot $\left(90 \mathrm{~m}^{2}\right)$ and bulked to make a composite sample. The samples were sent to Soil Fertility and Analytical Services Division (Department of Agriculture, Cedara) for chemical analysis according to standard methods of the NonAffiliated Soil Analysis Work Committee (1990).

Samples of effluent used during the study were collected from the AF (Season 1) and the HFCW (Season 2). These were analysed for $\mathrm{NH}_{4}^{+}-\mathrm{N}, \mathrm{NO}_{3}^{-} \mathrm{N}$ and $\mathrm{PO}_{4}^{3-}-\mathrm{P}$ according to standard methods (APHA, 2005).

\section{Experimental design, trial establishment and management}

A field experiment was laid out as a single factor analysis in a randomised complete block design (RCBD) with 3 blocks and 2 treatments: DEWATS effluent irrigation (DW) and tap water irrigation with fertiliser applied (TW). Banana (Musa acuminata var Williams) and taro (Colacasia esculentum) were grown in an intercrop, with taro as the minor crop between the banana rows.

Tissue-cultured banana seedlings were purchased from Zululand Nurseries, Eshowe, KwaZulu-Natal, and taro seed (Dumbe lomfula) was obtained from Ukulinga, University of KwaZulu-Natal Agricultural Research Farm. The two crops were selected due to the ability of the banana to bear fruits which are high above the ground and hence less likely to be contaminated by the effluent while taro is a crop that is commonly grown in South Africa and must be cooked before eating. Crops were planted on 13 November 2013 at a spacing of $3 \mathrm{~m} \times 1.5 \mathrm{~m}$ (banana) and $1 \mathrm{~m} \times 1 \mathrm{~m}$ intercrop (taro). The plots were $10 \mathrm{~m} \times 9 \mathrm{~m}\left(90 \mathrm{~m}^{2}\right)$ with 20 banana and 42 taro plants. Fertiliser was applied to the tap water + fertiliser-treated main crop based on soil chemical analysis results shown in Table 2. Fertiliser was not applied to taro although it required the amounts shown in Table 2 and was expected to benefit from the main crop in an intercrop. Split application of urea $(46 \% \mathrm{~N})$ was done for 8 months and $\mathrm{KCl}(52 \% \mathrm{~K})$ was done at 3-monthly intervals. The soil $\mathrm{P}$ test was greater than the target soil test (39.3 $\left.\mathrm{mg} \cdot \mathrm{L}^{-1}\right)$, hence $\mathrm{P}$ fertiliser was not applied.

The experiments were done over 2 cropping seasons whereby Season 1 was from banana planting to first harvest (November 2013-May 2015) and Season 2 was the first banana ratoon crop growing period until harvesting (July 2015-July 2016). During the experimental period, the DEWATS effluent used for irrigation was obtained from 2 different sources of the treatment system. The effluent was obtained from the HFCW (Season 1) and the AF (Season 2). Irrigation was applied using drippers with a delivery rate of $2 \mathrm{~L} \cdot$ plant $^{-1}$. The irrigation was applied 4 times a day for $1 \mathrm{~h}$ per irrigation event. Irrigation timing was controlled using a Rainbird ESP-Me automated switchboard. Soil profile moisture content was monitored by CS 650 soil water content reflectometers (Campbell Scientific, Inc.), inserted at 3 soil depths (0.3, 0.6 and $0.9 \mathrm{~m})$. Crop water stress through canopy temperature was monitored by a Precision Infrared Temperature Sensor (IRTSP) (Campbell Scientific, Inc.).

\section{Crop growth, yield and nutrient uptake}

All the data were collected from plants within the central $42 \mathrm{~m}^{2}$ quadrant of each $90 \mathrm{~m}^{2}$ plot, leaving all border rows. Sampling
TABLE 2

Nitrogen (N), phosphorus (P) and potassium (K) fertiliser requirements for banana and taro during the growing period for Season 1 (Nov 2013 - May 2015) and Season 2 (Jun 2015-July 2016) in respective irrigation treatments plots

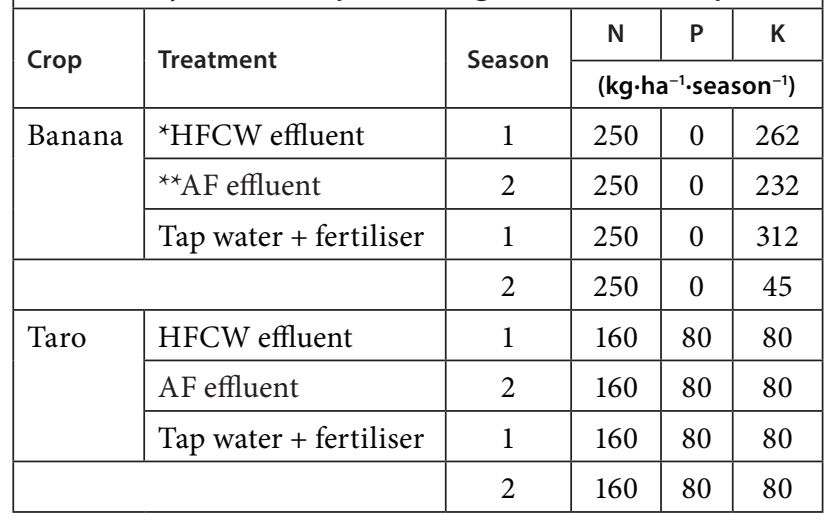

${ }^{*}$ Horizontal flow constructed wetland, ${ }^{* *}$ Anaerobic filter

was done from 6 banana ( $30 \%$ sample size) and 8 taro plants (20\% samples size). Banana and taro growth (crop height, number of leaves, leaf length and width and chlorophyll content) were measured during the 33 months of the experiment. The first harvest was done in May 2015 and the second in July 2016. Banana crop height was measured from the base of the plant to the bottom of the third-youngest mature leaf. Leaf length and width were measured on the third-youngest mature leaf. Taro crop height was measured from the bottom of the plant to the apex of the second-youngest leaf. Leaf area index (LAI) was determined following methods by Ghoreishi et al. (2012). Chlorophyll content was measured using a CCM 200-plus chlorophyll meter (Opti-Sciences, USA). Taro vegetative growth index (VGI) was calculated according to Eq. 1:

$$
V G I=\left(\frac{L A I \times P H}{100}\right)-(\text { suckers }- \text { stolons })^{2}
$$

where $V G I=$ vegetative growth index (dimensionless), $P H=$ plant height $(\mathrm{m}), L A I=$ leaf area index $\left(\mathrm{m}^{2} \cdot \mathrm{m}^{-2}\right)$.

Yield parameters of banana (number and mass of true fingers, bunch mass and peduncle mass) were used to calculate total yield (t.ha- $\left.{ }^{-1}\right)$ using Eq. 2:

Yield $=$ Number of fruits bunch ${ }^{-1} \times$ bunches $\cdot \mathrm{a}^{-1} \times$ mass of each fruit $(\mathrm{t})(2)$

Taro yield $\left(\mathrm{t} \cdot \mathrm{ha}^{-1}\right)$ was also determined after each of the two growing seasons and calculated from Eq. 3:

Yield $=$ Number of corms.plant ${ }^{-1} \times$ plants.ha ${ }^{-1} \times$ mass of each corm ( $\left.\mathrm{t}\right)$

After harvesting, the plants' fresh mass was determined. Banana is a succulent plant hence different plant parts were sampled (leaves, stem and bunch) and dried at $60^{\circ} \mathrm{C}$ for several days until a constant mass was attained. Taro corms were harvested and their mass determined fresh and after oven drying at $60^{\circ} \mathrm{C}$ for $72 \mathrm{~h}$.

Plant tissue samples of banana were collected by cutting the middle section of the lamina on the third-uppermost leaf at flowering stage. The leaves were oven dried at $60^{\circ} \mathrm{C}$ for $72 \mathrm{~h}$, crushed and passed through a $1 \mathrm{~mm}$ sieve. Taro corms were freeze dried, crushed and passed through a $1 \mathrm{~mm}$ sieve 
and sent to Soil Fertility and Analytical Services Division (Department of Agriculture, Cedara) for the analysis of macroand micronutrients following standard methods for plant tissue analysis by Kalra (1997). The crop nutrient uptake was calculated according to Eq. 4 :

Nutrient uptake $\left(\mathrm{kg} \cdot \mathrm{ha} \mathrm{a}^{-1}\right)=$ Nutrient concentration $\left(\mathrm{kg}^{\mathrm{kg}} \mathrm{kg}^{-1}\right) \times$ dry biomass $\left({\left.\mathrm{kg} \cdot h \mathrm{a}^{-1}\right)}^{-1}\right.$

\section{Crop water requirements}

A Campbell Scientific automated weather station (AWS) with a CR 1000 datalogger (Campbell Scientific Inc., Utah, USA) installed $10 \mathrm{~m}$ away from the experimental field was used to collect meteorological data. The AWS measured the reference evapotranspiration ( $E T_{\mathrm{o}}$ in $\mathrm{mm}$ ) according to a Food and Agriculture Organisation (FAO) equation (Allen, 1998). The crop evapotranspiration was calculated as a product of potential evapotranspiration $\left(E T_{\mathrm{o}}\right)$ and specific crop factors $\left(K_{\mathrm{c}}\right)$ (FAO, 2015) as shown in Eq. 5:

$$
E T_{\text {crop }}=E T_{O} \times K_{C}
$$

where: $E T_{\text {crop }}(\mathrm{mm}), E T_{\mathrm{o}}(\mathrm{mm})$ and $K_{\mathrm{c}}$ (dimensionless).

The land area required was estimated from the crop water requirements based on annual crop evapotranspiration and rainfall data collected (Eq. 6):

$$
A=\frac{D W C}{I R \times h h n}
$$

where: $A=$ area $\cdot$ household ${ }^{-1}\left(\mathrm{~m}^{2}\right) ; h h n=$ number of households; $D W C=$ DEWATS wastewater production capacity $(\mathrm{L}) ; I R=$ crop irrigation requirements $\left(\mathrm{L} \cdot \mathrm{ha}^{-1}\right)$

\section{Data analysis}

All the data collected were analysed using GenStat $18^{\text {th }}$ Edition (VSN International, UK). Analysis of variance (ANOVA) was conducted to show differences between the main factors and their interactions (where applicable) at the 5\% significance level. Differences between means were separated using standard error of deviation (SEDs) at 5\% significance level.

\section{RESULTS AND DISCUSSION}

\section{Characterisation of DEWATS effluent}

Selected chemical characteristics of the DEWATS effluent used for irrigating crops during the study are given in Table 3. According to the Department of Water Affairs revision of general authorisations in terms of section 39 of the National Water Act (Act No. 36 of 1998) regulations, when $50 \mathrm{~m}^{3}$ of domestic wastewater is used for irrigation on a daily basis standards described in Table 3 must be met (DWA, 2013). The Act does not restrict any concentrations of nutrients ( $\mathrm{N}$ and $\mathrm{P}$ ) for irrigation with $50 \mathrm{~m}^{3}$ of effluent per day.

\section{Crop growth}

Analysis of variance for taro and banana growth between the two irrigation treatments are shown in Table 4. Significant differences $(P<0.001)$ in crop growth between the two irrigation treatments were observed with regards to taro plant height. An interaction between the irrigation treatments and season in taro was observed with regards to VGI $(P<0.05)$ and LAI $(P<0.01)$.

The effects of the irrigation treatments on taro plant height are shown in Figure 2. The mean plant height was higher in the DEWATS effluent irrigation treatment $(0.32 \mathrm{~m})$ compared to tap water irrigation + fertiliser $(0.28 \mathrm{~m})$. The result was due to mineral nutrients from the DEWATS effluent. This agrees with

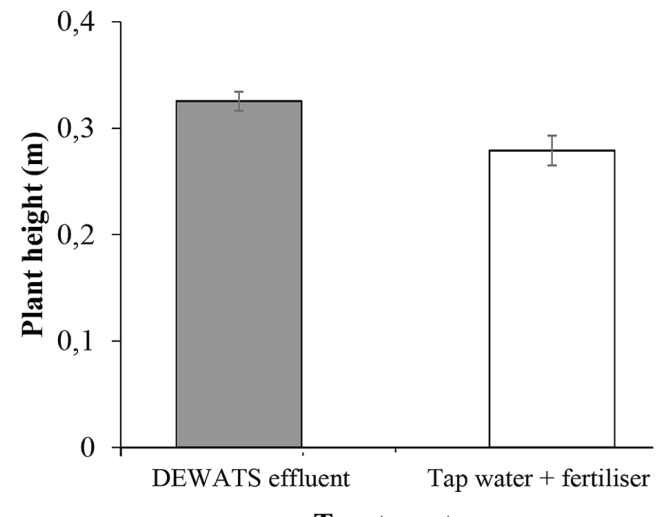

Treatment

Figure 2

The effect of irrigation water (DEWATS effluent vs tap water + fertiliser)

\begin{tabular}{|c|c|c|c|}
\hline \multicolumn{4}{|c|}{$\begin{array}{c}\text { TABLE } 3 \\
\mathrm{NH}_{4}^{+-}-\mathrm{N}, \mathrm{NO}_{3}^{-} \mathrm{N} \text { and } \mathrm{PO}_{4}^{3-}-\mathrm{P} \text { (mean } \pm \text { standard error of deviation and range) in wastewater } \\
\text { samples from different effluent sources ( } \mathrm{AF} \text { and } \mathrm{HFCW} \text { ) at Newlands-Mashu in comparison to } \\
\text { DWA daily standards for irrigation water quality }\end{array}$} \\
\hline \multirow{2}{*}{ Wastewater } & $\mathrm{NH}_{4}^{+}-\mathrm{N}$ & $\mathrm{NO}_{3}^{-\mathrm{N}}$ & $\mathrm{PO}_{4}^{3-}-\mathrm{P}$ \\
\hline & \multicolumn{3}{|c|}{$\left(\mathrm{mg} \cdot \mathrm{L}^{-1}\right)$} \\
\hline Limit (DWA, 2013) up to $2000 \mathrm{~m}^{3} \cdot$ day $^{-1}$ & 3 & 15 & 10 \\
\hline Limit (DWA, 2013) up to $500 \mathrm{~m}^{3} \cdot$ day $^{-1}$ & $\mathrm{na}^{*}$ & na & na \\
\hline Limit (DWA, 2013) up to $50 \mathrm{~m}^{3} \cdot$ day $^{-1}$ & na & na & na \\
\hline AF effluent & $\begin{array}{c}55.34 \pm 5.67 \\
\text { range: } 21.1-89\end{array}$ & $\begin{array}{c}0.63 \pm 0.27 \\
\text { range: } 0-3\end{array}$ & $\begin{array}{c}14.6 \pm 0.13 \\
\text { range: } 7.6-19\end{array}$ \\
\hline HFCW & $\begin{array}{c}6.7 \pm 1.02 \\
\text { range: } 5-7.9\end{array}$ & $\begin{array}{c}12.73 \pm 7.9 \\
\text { range: } 3.1-25\end{array}$ & $\begin{array}{l}4.13 \pm 0.55 \\
\text { range: } 3-6\end{array}$ \\
\hline
\end{tabular}
on average taro plant height ( $\mathrm{n}=3 \pm$ standard error of mean deviation)

${ }^{*}$ not applicable. AF ( $\mathrm{n}=10 \pm$ standard error of mean deviation), HFCW ( $\mathrm{n}=3 \pm$ standard error of mean deviation); DWA $=$ Department of Water Affairs. 
studies by Uzen et al. (2016) who reported increased yield in domestic wastewater-irrigated cotton.

The LAI and VGI of taro in response to the irrigation treatments for each season are shown in Fig. 3. Taro growth was generally higher during the first season (November 2013 to May 2015) compared to the second season (July 2015 to July 2016), probably because in the first season the taro established faster due to a less complete banana canopy compared to the second season.

\section{Effluent requirements per unit area}

The rainfall and total evapotranspiration for the two crops (banana and taro) between planting (November 2013) and final harvest (July 2016) are presented in Fig. 4. The data show a seasonal variation in rainfall and crop water demands typical of the sub-tropical climate at the experimental site. Higher crop water requirements were recorded during the summer months (September to April) compared to winter (May to August). During the study, the highest winter rainfall was recorded in July 2016. There were two periods in July 2015 and July 2016 when irrigation deficit was very low (rainfall higher than evapotranspiration). Although crop water demand was high in summer, rainfall sometimes supplemented irrigation requirements.

Over the 33-month growing period the total amount of effluent that could be irrigated on the banana/taro intercrop was $3514 \mathrm{~mm}\left(35.14 \mathrm{ML} \cdot \mathrm{ha}^{-1}\right)$. Considering a total annual DEWATS effluent production rate of $12.5 \mathrm{ML} \cdot \mathrm{yr}^{-1}$ and the deficit of $12.8 \mathrm{ML} \cdot \mathrm{yr}^{-1}$ (35.14 ML per 33 months), all the effluent is likely to balance the banana/taro crop water requirements. Since irrigation is based on variable crop water requirements, temporary storage is required in periods when irrigation is not required. High rainfall exceeding crop water requirements $\left(E T_{\text {crop }}\right)$ was received in July month, with a surplus of $211 \mathrm{~mm}$ per 33 months $\left(77 \mathrm{~mm} \cdot \mathrm{yr}^{-1}\right)$.

The data recorded for actual water applied with regards to the respective DEWATS effluent sources (AF and HFCW) are given in Table 5. The total amount of HFCW effluent used to irrigate the main banana crop and the taro first-year crop (June 2014 to May 2015) was $1130 \mathrm{~mm}$, and thereafter AF effluent was used for irrigation (June 2015 to July 2016) such that $1642 \mathrm{~mm}$ was applied (Table 5). During the entire growing period (November 2013 to July 2016), including 6 months of no irrigation (November 2013 to May 2014), the total effluent used for irrigation was $2772 \mathrm{~mm}$ instead of the $3514 \mathrm{~mm}$ required by the crops.

As explained earlier, the total amount of effluent produced by the DEWATS plant at Newlands-Mashu is $35 \mathrm{~m}^{3}$. day ${ }^{-1}$ $\left(12.5 \mathrm{ML} \cdot \mathrm{yr}^{-1}\right)$. If the crops could have been irrigated during the whole experimental period, an amount of $3514 \mathrm{~mm}$
(1 $277 \mathrm{~mm} \cdot \mathrm{yr}^{-1}$ ) was required. Thus, to use all the effluent produced based on crop water requirements about 0.97 ha of land would be required. Considering that there are 83 households and assuming 5 people per household, 0.0117 ha.household ${ }^{-1}$ $\left(23.3 \mathrm{~m}^{2}\right.$.person $\left.{ }^{1}\right)$ would be needed. During wet periods effluent can be stored for later use and based on the calculations made in Fig. 4 with reference to the climate at NewlandsMashu about $211 \mathrm{~mm} \cdot \mathrm{yr}^{-1}\left(770 \mathrm{~m}^{3}\right)$ of excess effluent will be produced. Therefore, the storage requirements needed will be $9.2 \mathrm{~m}^{3} \cdot$ household $^{-1}\left(1.9 \mathrm{~m}^{3} \cdot\right.$ person $\left.^{-1}\right)$.
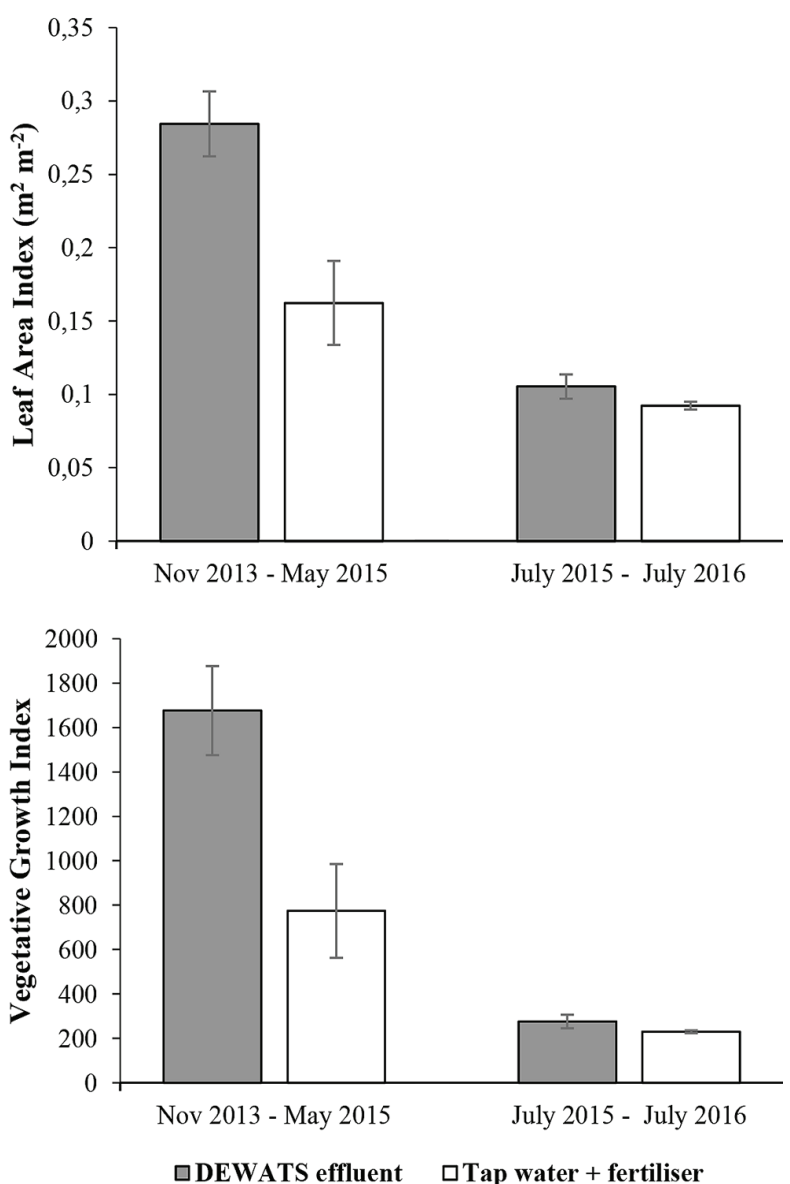

Figure 3

Average ( $n=3 \pm$ standard error of mean deviation) vegetative growth index (dimensionless) and leaf area index of taro with the two irrigation treatments (tap water + fertiliser and DEWATS effluent) for each season

\begin{tabular}{|c|c|c|c|c|c|c|c|}
\hline \multicolumn{8}{|c|}{$\begin{array}{l}\text { TABLE } 4 \\
\begin{array}{c}\text { Analysis of variance showing the probability values for banana and taro growth between the two irrigation } \\
\text { treatments over two growing seasons }\end{array}\end{array}$} \\
\hline \multirow[b]{2}{*}{ Source of variation } & \multirow[b]{2}{*}{ D.F. } & \multicolumn{3}{|c|}{ Banana } & \multicolumn{3}{|c|}{ Taro } \\
\hline & & $\mathrm{PH}$ & $\mathrm{CCl}$ & LAI & $\mathrm{PH}$ & VGI & LAI \\
\hline Block & 2 & & & & & & \\
\hline Season & 1 & $0.005^{\star *}$ & 0.868 & 0.574 & $0.034^{*}$ & $0.012^{*}$ & $0.008^{\star *}$ \\
\hline Treatment & 1 & 0.621 & 0.123 & 0.877 & $<0.001^{\star * *}$ & $<0.001^{\star * *}$ & $<0.001^{\star * *}$ \\
\hline Season $\times$ treatment & 1 & 0.648 & 0.765 & 0.854 & 0.064 & $0.022^{*}$ & $0.03^{* *}$ \\
\hline
\end{tabular}

$D F=$ degrees of freedom; $P H=$ plant height $C C I=$ chlorophyll content index $; A I=$ leaf area index; $V G I=$ vegetative growth index. ${ }^{*} \mathrm{p}<0.05,{ }^{* *} \mathrm{p}<0.01,{ }^{* * *} \mathrm{p}<0.001$ 
TABLE 5

Irrigation data at Newlands-Mashu field experiment for the period June 2014 to July 2016

\begin{tabular}{|c|c|c|c|c|c|}
\hline Month-year & Days irrigated & $\begin{array}{l}\text { Irrigation per plant } \\
\text { (L) }\end{array}$ & $\begin{array}{l}\text { Taro irrigation } \\
(\mathrm{mm})\end{array}$ & $\begin{array}{c}\text { Banana irrigation } \\
(\mathrm{mm})\end{array}$ & $\begin{array}{c}\text { Banana/taro irrigation } \\
(\mathrm{mm})\end{array}$ \\
\hline \multicolumn{6}{|l|}{ Season 1} \\
\hline Jun-14 & 12 & 96 & 45 & 21 & 66 \\
\hline Jul-14 & 31 & 248 & 116 & 55 & 171 \\
\hline Aug-14 & 30 & 240 & 112 & 53 & 165 \\
\hline Sep-14 & 30 & 240 & 112 & 53 & 165 \\
\hline Oct-14 & 30 & 240 & 112 & 53 & 165 \\
\hline Nov-14 & 20 & 160 & 70 & 36 & 106 \\
\hline Dec-14 & 26 & 208 & 97 & 46 & 143 \\
\hline Jan-15 & 12 & 96 & 45 & 21 & 66 \\
\hline Feb-15 & 0 & 0 & 0 & 0 & 0 \\
\hline Mar-15 & 10 & 80 & 37 & 18 & 55 \\
\hline Apr-15 & 5 & 40 & 19 & 9 & 28 \\
\hline Total & 206 & 1648 & 765 & 365 & 1130 \\
\hline \multicolumn{6}{|l|}{ Season 2} \\
\hline May-15 & 0 & 0 & 0 & 0 & 0 \\
\hline Jun-15 & 0 & 0 & 0 & 0 & 0 \\
\hline Jul-15 & 10 & 80 & 37 & 18 & 55 \\
\hline Aug-15 & 18 & 144 & 67 & 32 & 99 \\
\hline Sep-15 & 16 & 128 & 60 & 28 & 88 \\
\hline Oct-15 & 12 & 96 & 45 & 21 & 66 \\
\hline Nov-15 & 13 & 104 & 49 & 23 & 72 \\
\hline Dec-15 & 10 & 80 & 37 & 18 & 55 \\
\hline Jan-16 & 0 & 0 & 0 & 0 & 0 \\
\hline Feb-16 & 10 & 19 & 9 & 4 & 13 \\
\hline Mar-16 & 23 & 88 & 41 & 23 & 64 \\
\hline Apr-16 & 24 & 103 & 48 & 23 & 71 \\
\hline May-16 & 25 & 105 & 49 & 23 & 72 \\
\hline Jun-16 & 30 & 1073 & 501 & 239 & 740 \\
\hline Jul-16 & 17 & 358 & 167 & 80 & 247 \\
\hline Total & 208 & 2378 & 1110 & 532 & 1642 \\
\hline
\end{tabular}

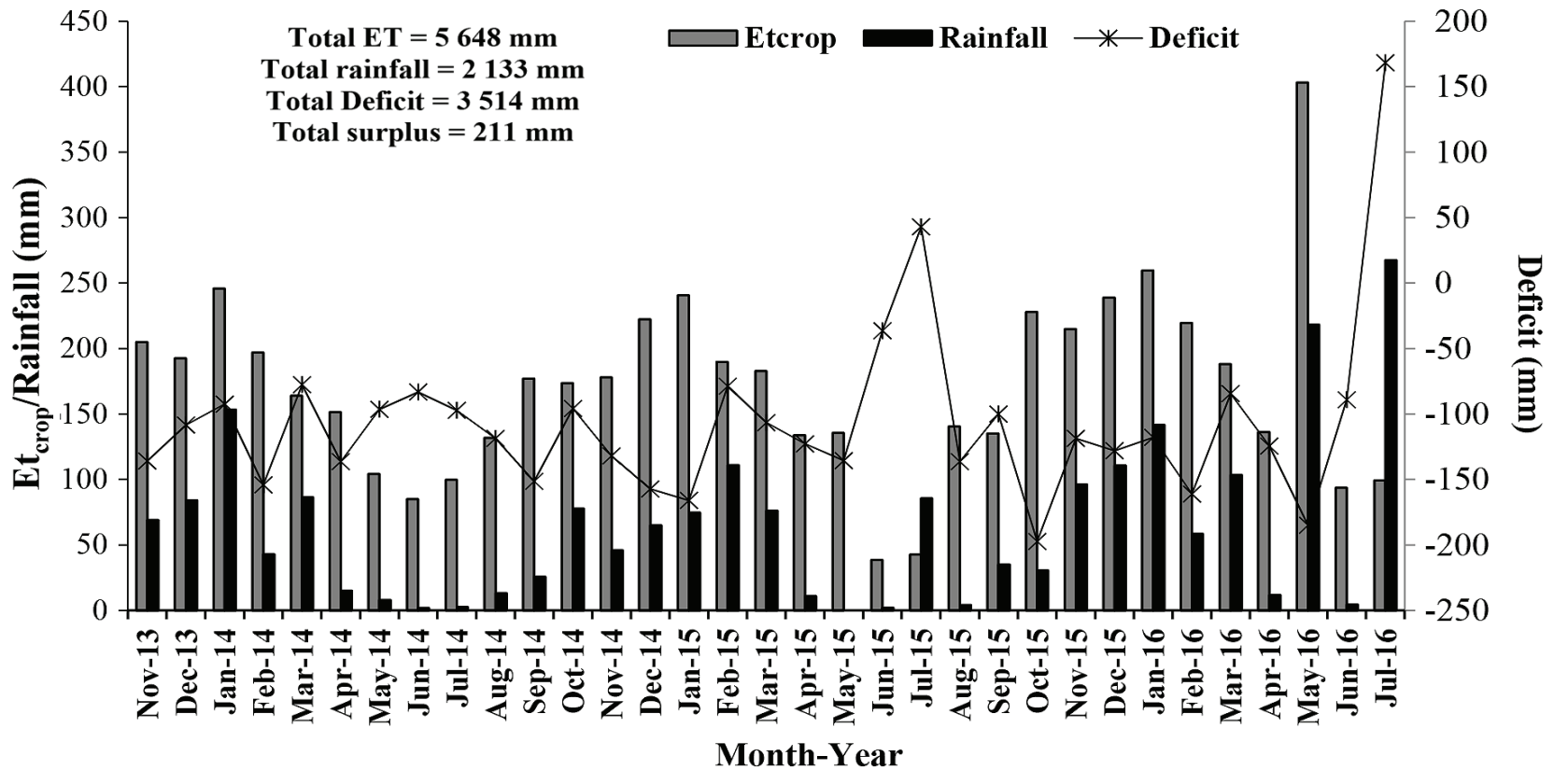

Figure 4

Rainfall and evapotranspiration (ET for both banana and taro) and irrigation deficits at the Newlands-Mashu field site showing irrigation water demands for the period between November 2013 and July 2016 


\section{Effluent as a source of fertiliser ( $\mathrm{N}$ and $\mathrm{P}$ ) for banana and taro}

The $\mathrm{N}$ and $\mathrm{P}$ supplied by irrigating the banana and taro crops with DEWATS effluent are given in Table 6. During the growing season, the $\mathrm{N}$ and $\mathrm{P}$ requirements for both crops were met. Although there was a deficit of about $742 \mathrm{~mm}$ when irrigation was not done (Nov 2013 to May 2014), the total applied still met the crop nutrient requirements.

The amount of nutrients that could have been supplied if crops were irrigated with effluent from the HFCW or the AF based on crop water requirements are shown in Fig. 5. The results show that if HFCW effluent was used, half of the nutrients required will be supplied $\left(683 \mathrm{~kg} \cdot \mathrm{ha}^{-1} \mathrm{~N}\right.$ and $145 \mathrm{~kg} \cdot h \mathrm{~h}^{-1} \mathrm{P}$ ). If AF effluent were to be used exclusively, the amounts supplied will be much greater than required (2 $144 \mathrm{~kg} \cdot \mathrm{ha}^{-1} \mathrm{~N}$ and $514 \mathrm{~kg} \cdot \mathrm{ha}^{-1} \mathrm{P}$ ).

Scenarios to determine the irrigation requirements if effluent from different sources (HFCW and AF) were to be used to meet crop $\mathrm{N}$ and $\mathrm{P}$ requirements are shown in Fig. 6 . To meet nutrients required by the two test crops, $5824 \mathrm{~mm}$ (HFCW) and $1849 \mathrm{~mm}$ (AF) will be required for $\mathrm{N}$ and $5327 \mathrm{~mm}$ (HFCW) and $1507 \mathrm{~mm}$ (AF) for P.

These observations show that when HFCW effluent is used for irrigating crops through scheduling, there might be a need to supplement with $\mathrm{N}$ and $\mathrm{P}$. On the other hand, irrigation with AF effluent at Newlands-Mashu will likely provide more $\mathrm{N}$ and $\mathrm{P}$ compared to the amounts required by crops. It is very important to monitor nutrient dynamics in the soils irrigated with AF effluent to prevent environmental contamination.

\section{CONCLUSIONS}

Irrigation with DEWATS effluent was comparable to tap water + fertiliser, especially for banana. Over the 33-month period banana and taro required $3514 \mathrm{~mm}$ of effluent. About 0.0117 ha.household ${ }^{-1}\left(23.3 \mathrm{~m}^{2}\right.$.person $\left.{ }^{-1}\right)$ is needed under the conditions studied at Newlands-Mashu. Storage requirements needed during wet periods were calculated to be about $767 \mathrm{~m}^{3}\left(9.2 \mathrm{~m}^{3}\right.$.household ${ }^{-1}$ or $1.9 \mathrm{~m}^{3} \cdot$ person $\left.{ }^{-1}\right)$. The horizontal flow wetland effluent can supply adequate water but not all of the $\mathrm{N}$ and $\mathrm{P}$ required by banana and taro. Monitoring of the amounts of $\mathrm{N}$ and $\mathrm{P}$ supplied will be required when anaerobic filter effluent is used to irrigate banana and taro based on their crop water requirements.

TABLE 6

Nitrogen $(\mathrm{N})$ and phosphorus $(\mathrm{P})$ supplied by irrigation with effluent from the two different sources based on actual amounts applied over 33 months in comparison to crop nutrient requirements for both crops

\begin{tabular}{|l|r|c|}
\hline \multirow{2}{*}{ Effluent source } & N & P \\
\cline { 2 - 3 } & \multicolumn{2}{|c|}{$\left(\mathbf{k g} \cdot \mathbf{h a}^{-1}\right)$} \\
\hline AF & 1000 & 220 \\
\hline HFCW & 239 & 47 \\
\hline Total applied & 1239 & 267 \\
\hline Total required & 1128 & 220 \\
\hline
\end{tabular}

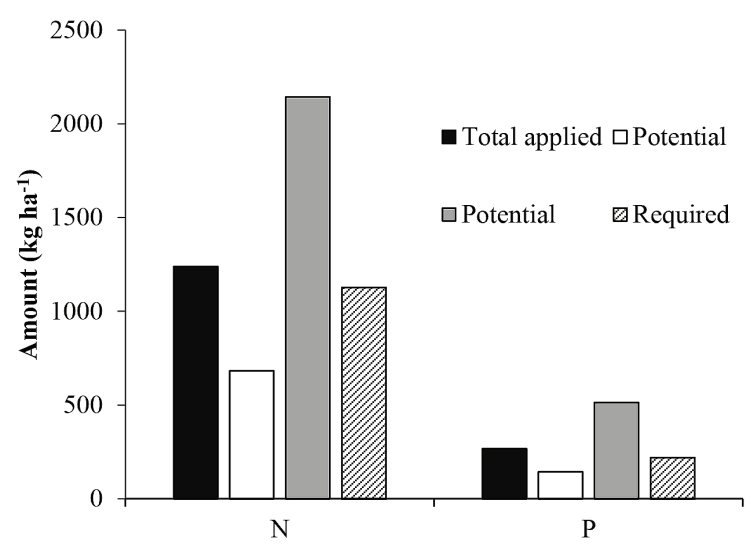

Figure 5

Nitrogen $(N)$ and phosphorus $(P)$ supplied from different sources of DEWATS effluent (anaerobic filter (AF) and horizontal flow wetland (HFCW)) based on actual irrigation applied and potential irrigation when the crop water requirements are met over the 33 months period.

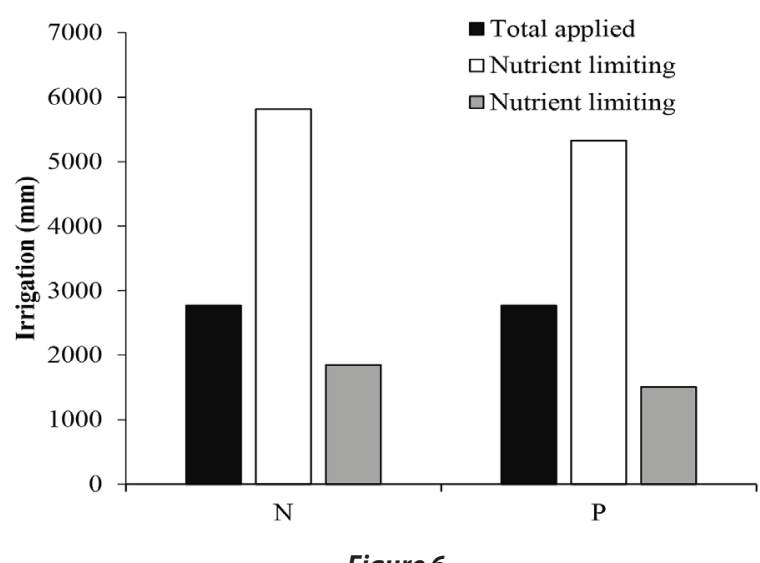

Figure 6

Irrigation required to meet the nitrogen $(N)$ and phosphorus $(P)$ requirements for the two crops from two irrigation water sources (anaerobic filter (AF) and horizontal flow wetland HFCW))

\section{ACKNOWLEDGEMENTS}

The research was carried out under Project No. K5/2220 (Integrating Agriculture in Designing On-Site, Low Cost Sanitation Technologies in Social Housing Schemes) of the Water Research Commission of South Africa. Further acknowledgements go to Bremen Overseas Research and Development Association (BORDA) and the eThekwini Water and Sanitation (EWS) Department.

\section{REFERENCES}

ALLEN RG (1998) Crop evapotranspiration - Guidelines for computing crop water requirements. FAO Irrigation and Drainage Paper 56. FAO, Rome.

ALMUKTAR SAAAN, SCHOLZ M, AL-ISAWI RHK and SANI A (2015) Recycling of domestic wastewater treated by vertical-flow wetlands for irrigating chillies and sweet peppers. Agric. Water Manage. 149 1-22. https://doi.org/10.1016/j.agwat.2014.10.025.

APHA (2005) Standard Methods for the Examination of Water and Wastewater. American Public Health Association, Washington DC. ASHIPALA N and ARMITAGE N (2011) Impediments to the adoption of alternative sewerage in South African urban informal settlements. Water Sci. Technol. 64 (9) 1781-1789 https://doi. org/10.2166/wst.2011.746. 
BAME IB, HUGHES JC, TITSHALL LW and BUCKLEY CA (2013) Leachate characteristics as influenced by application of anaerobic baffled reactor effluent to three soils: a soil column study. Chemosphere 93 (9) 2171-2179 http://dx.doi.org/10.1016/j.chemosphere.2013.07.080.

BARBER WP and STUCKEY DC (1999) The use of the anaerobic baffled reactor (ABR) for wastewater treatment: a review. Water Res. 33 (7) 1559-1578 http://dx.doi.org/10.1016/S0043-1354(98)00371-6.

CROSS $\times$ and BUCKLEY C (2016) SFD Report - Durban, South Africa. SFD Promotion Initiative, Durban.

DWA (Department of Water Affairs, South Africa) (2013) Revision of general authorisations in terms of Section 39 of the National Water Act, 1998. Government Gazette 36820. Government Printer, Pretoria.

FAO (2015) Crop water information: Banana. URL: http://www.fao. org/nr/water/cropinfo_banana.html (Accessed 15 July 2015).

FONSECA AFD, HERPIN U, PAULA AMD, VICTÓRIA RL and MELFI AJ (2007) Agricultural use of treated sewage effluents: agronomic and environmental implications and perspectives for Brazil. Sci. Agric. 64 194-209. https://doi.org/10.1590/ S0103-90162007000200014.

FOXON K, PILLAY S, LALBAHADUR T, RODDA N, HOLDER F and BUCKLEY C (2005) The anaerobic baffled reactor (ABR): an appropriate technology for on-site sanitation. Water $S A 30$ (5) 44-50. http://dx.doi.org/10.4314/wsa.v30i5.5165.

GHOREISHI M, HOSSINI Y and MAFTOON M (2012) Simple models for predicting leaf area of mango (Mangifera indica L.). J. Biol. Earth Sci. 2 (2) 45-53. https://doi.org/10.1016/j.scienta.2017.10.034.

GUTTERER B, SASSE L, PANZERBIETER T and RECKERZÜGEL T (2009) Decentralised wastewater treatment systems (DEWATS) and sanitation in developing countries. BORDA, Bremen.

HOOSSEIN S, WHITTINGTON-JONES K and TANDLICH R (2014) Sanitation policy and prevention of environmental contamination in South Africa. Environ. Eng. Manage. J. 13 (6) 1335-1340.

HUSSAIN I, RASCHID L, HANJRA MA, MARIKAR F and VAN DER HOEK W (2002) A framework for analyzing socioeconomic, health and environmental impacts of wastewater use in agriculture in developing countries. International Water Management Institute Working Paper 26. IWMI, Colombo, Sri Lanka.

JOVANOVIC N, ANNANDALE J and MHLAULI N (1999) Field water balance and SWB parameter determination of six winter vegetable species. Water SA 25 (2) 191-196.

KADLEC RH and WALLACE S (2008) Treatment Wetlands. CRC Press, New York.

KALRA Y (1997) Handbook of Reference Methods for Plant Analysis. CRC Press, New York. https://doi.org/10.1201/9781420049398

LAVROVA S and KOUMANOVA B (2013) Nutrients and organic matter removal in a vertical-flow constructed wetland. In: Yogesh $\mathrm{BP}$ and Prakashs R (eds) Applied Bioremediation - Active and Passive Approaches. Intech Open Science Online Publisher, Croatia. 69-99. http://dx.doi.org/10.5772/56245.
MATEO-SAGASTA J, MEDLICOTT K, MANZOR Q, RASCHIDSALLY L, DRECHSEL P and LIEBE J (2013) Proceedings of the UN-Water project on the: Safe Use of Wastewater in Agriculture. United Nations-Water project. UNW-DPC, Bonn.

MOUSAVI SR, TAVAKOLI MT, DADGAR M, CHENARI AI, MORIDIYAN A and SHAHSAVARI M (2015) Reuse of treated wastewater for agricultural irrigation with its quality approach. Biol. Forum 7 (1) 814-822.

NON-AFFILIATED SOIL ANALYSIS WORK COMMITTEE and SOIL SCIENCE SOCIETY OF SOUTH AFRICA (1990) Handbook of Standard Soil Testing Methods for Advisory Purposes. Soil Science Society of South Africa, Pretoria.

PEDRERO F, KALAVROUZIOTIS I, ALARCÓN JJ, KOUKOULAKIS $P$ and ASANO T (2010) Use of treated municipal wastewater in irrigated agriculture-Review of some practices in Spain and Greece. Agric. Water Manage. 97 (9) 1233-1241. https://doi. org/10.1016/j.agwat.2010.03.003.

SASSE L (1998) DEWATS: Decentralised Wastewater Treatment in Developing Countries. BORDA, Bremen Overseas Research and Development Association, Bremen.

SCHULZE RE (1997) South African Atlas of Agrohydrology and-Climatology. WRC Report No. TT82/96. Water Research Commission, Pretoria.

SINGH S, HABERL R, MOOG O, SHRESTHA RR, SHRESTHA P and SHRESTHA R (2009) Performance of an anaerobic baffled reactor and hybrid constructed wetland treating high-strength wastewater in Nepal-A model for DEWATS. Ecol. Eng. 35 (5) 654-660. https:// doi.org/10.1016/j.ecoleng.2008.10.019.

SOIL CLASSIFICATION WORKING GROUP (1991) Soil Classification: A Taxonomic System for South Africa. Department of Agricultural Development, Pretoria.

SOIL SURVEY STAFF (2014) Keys to Soil Taxonomy. 20402. USDA, Washington DC, USA

UZEN N, CETIN O and UNLU M (2016) Effects of domestic wastewater treated by anaerobic stabilization on soil pollution, plant nutrition, and cotton crop yield. Environ. Monit. Assess. 188 (12) 664 https://doi.org/10.1007/s10661-016-5680-x.

VINNERÅS B (2002) Possibilities for sustainable nutrient recycling by faecal separation combined with urine diversion. $\mathrm{PhD}$ thesis. Acta Universitatis Agriculturae Sueciae, Swedish University of Agricultural Sciences, Uppsala, Sweden.

VYMAZAL J (2007) Removal of nutrients in various types of constructed wetlands. Sci. Total Environ. 380 (1) 48-65. https://doi. org/10.1016/j.scitotenv.2006.09.014.

YE F and LI Y (2009) Enhancement of nitrogen removal in towery hybrid constructed wetland to treat domestic wastewater for small rural communities. Ecol. Eng. 35 (7) 1043-1050. https://doi. org/10.1016/j.ecoleng.2009.03.009. 